\title{
ECO-EFFICIENT EARTHEN PLASTERS. THE INFLUENCE OF THE ADDITION OF NATURAL FIBERS
}

\author{
José Lima $^{1(*)}$, Paulina Faria ${ }^{2}$ \\ ${ }^{1}$ Faculty of Architecture, University of Lisbon, Alto da Ajuda, Portugal. \\ ${ }^{2}$ Department of Civil Engineering, NOVA University of Lisbon, Caparica, Portugal \\ ${ }^{(*)}$ Email: jose.lima.ferreira@gmail.com
}

\begin{abstract}
Clayish earth-based mortars are been recognized, all over the world, as eco-efficient products for plastering. Apart from being a product with low embodied energy when compared to other types of plasters, their application on the interior surface of walls may give a strong contribution for the health and comfort of inhabitants. As part of an ongoing research regarding earth-based plasters this work assesses the influence of the addition of two types of natural fibres - oat straw and typha fiber-woll - on the characteristics of plastering mortars made with a clayish earth. Mechanical and physical characteristics were tested, showing that addition of these fibers contribute to decrease linear drying shrinkage and thermal conductivity, as well as promoting the adhesion strength of plaster to the substrate. The improvement of mechanical resistance reveal to be dependent on the type of fiber added while the hygroscopic capacity of the plaster is maintained regardless of the fiber additions.
\end{abstract}

\section{INTRODUCTION}

There is an increasing international interest regarding earth-based mortars due to its recognition as eco-efficient products, namely for indoor plastering, since they can contribute to improve some import aspects of building performance related to health and comfort of inhabitants, as well as building sustainability.

Earth-based mortars can contribute to building life cycle sustainability mainly due to its low embodied energy. That derives from the use of raw clay as a natural binder, without the need of any heat treatment, and from wide availability of local resources of clayish earth all over the globe, allowing the mitigation of ecological impact of long distance transportations (Mèlia et al., 2014). Another contribution of earth-based mortars for building life cycle sustainability comes from the fact that earth-based mortars, produced without addition of any chemical stabilizer like cement or lime, can be easily recycled just with low consumption of mechanical energy and the addiction of water. Furthermore the use of clayish earth as raw material does not directly lead to any pollutant emissions during building life cycle therefore mitigating contamination hazards even in an eventual end of life disposal (Minke, 2006).

Due to high hygroscopicity of the clay minerals (Botelho-Costa, 1973; Gomes, 1988), earthbased mortars present a high adsorption and desorption capacity, particularly when compared to other type of mortars for interior plastering (Minke, 2006). This capacity allows earthbased plasters to act as a moisture buffer, contributing to balance the relative humidity of the indoor environment of buildings (Minke, 2006; Maddison et al., 2009; Liuzzi et al., 2013).

This high humidity buffering capacity of earth-based plasters promotes the comfort and health of inhabitants. Firstly because a high relative humidity environment increase the discomfort 
associated with the perception of heat or cold (Moret-Rodrigues et.al., 2009). And secondly because by balancing the relative humidity of the indoor environment earth-based plasters contribute, in one hand, to mitigate health conditions associated with high relative humidity, like infections, allergies or asthma, and in another hand, contribute also to mitigate the probability of mucosal membranes irritation and inflammation associated to exceedingly dry indoor environments (WHO, 2009).

Earth-based plasters may also contribute to indoor air quality since clay can act as a passive removal material (PRM), lowering indoor ozone concentrations, and therefore lowering the probability of occurrence of indoor ozone reaction with other building materials. This may lead to lower concentrations of oxidized reactions products, which could be toxic and irritating to mucosal membranes and other tissues (Lamble et al., 2011; Darling et al., 2012).

Despite the increase of interest in earth-based plasters there is still no European standards for this type of mortars, except in Germany where standard DIN 18947 (DIN, 2013) on the subject was released recently. Thenceforth that standard has been followed by several scientific studies regarding the assessment of mechanical and physical properties of this type of mortars (Delinière, 2014; Faria et al., 2014; Lima and Faria, 2014).

As part of an ongoing research regarding earth-based plasters specifically formulated with clayish earth extracted from Algarve sedimentary basin, which revealed a high potential for interior plastering (Lima and Faria, 2014), the present study also follows that DIN standard and aim to assess the addition of two natural fibers to the plastering mortar, namely, oat straw and cattail seed fibers (Typha latifolia L.), also known as typha fiber-wool. While oat straw is a relatively common raw material in earthen architecture construction systems, such as adobe, cob or wattle and daub, the use of typha fiber-wool as a reinforcement for earth-based plasters only got the focus of international scientific community in recent years (Maddison et al., 2009; Georgiev et al., 2013).

For this assessment six mortars were formulated with the same volumetric proportions of clayish earth and siliceous sand, respectively 1:3. One was considered the reference mortar, without any fiber addition, while the other five mortars were added with different amounts of oat straw or typha fiber-wool. The mortars were assessed in fresh state considering water contents, wet density, flow table consistency. The plaster samples were assessed in harden state, considering linear shrinkage, flexural and compressive strength, adhesive strength, thermal conductivity and adsorption and desorption capacity.

\section{MATERIALS}

All the six mortars assessed in this work were formulated with the same clayish earth extracted from a clay quarry located in the East sector of "Barrocal" sub-region of Algarve, in Southern Portugal. This sub-region is set in the highest area of Algarve sedimentary basin and presents a high concentration of clayey soils with a mineralogy dominated by the ilite clay mineral, mainly as consequence of a sedimentogenesis process based in a marine environment. The selected clay quarry integrate a group of clay quarries located in geologic formations from the Rhaetian / Hettangian age, in the transition from Triassic to Jurassic period, that present the very high predominance of the ilite clay mineral (Manuppella, 1985; Lima and Faria, 2014).

The ilite clay mineral concentration was the key factor to select the clayish earth for the development of this study since it is characterized by a significant water vapor adsorption capacity combined with low swelling when wetted. These characteristics are due to ilite 
alumino-silicate crystalline structure arranged in a succession of tetrahedron/octahedron/tetrahedron layers, with a interlayer space mainly occupied by potassium cations responsible for the lowered swelling (Botelho-Costa, 1973; Gomes, 1988). These properties are most important for interior plastering because maximize the moisture buffering capacity of the plaster and simultaneously mitigate the chance of the occurrence of shrinkage cracking during their drying.

The clayish earth was extracted and was mechanically disaggregated and sieved at $2 \mathrm{~mm}$. The particle size distribution of the disaggregated clayish earth was analyzed by dry sieving according to standard EN 1015-1 and is presented in Figure 1.

The siliceous sand selected for developing this experiment was extracted from a quarry located in Santiago do Cacém, in Setubal region, South West cost of Portugal. The particle size distribution of the selected sand was analyzed by dry sieving according to standard EN 1015-1 and is presented in Figure 1.

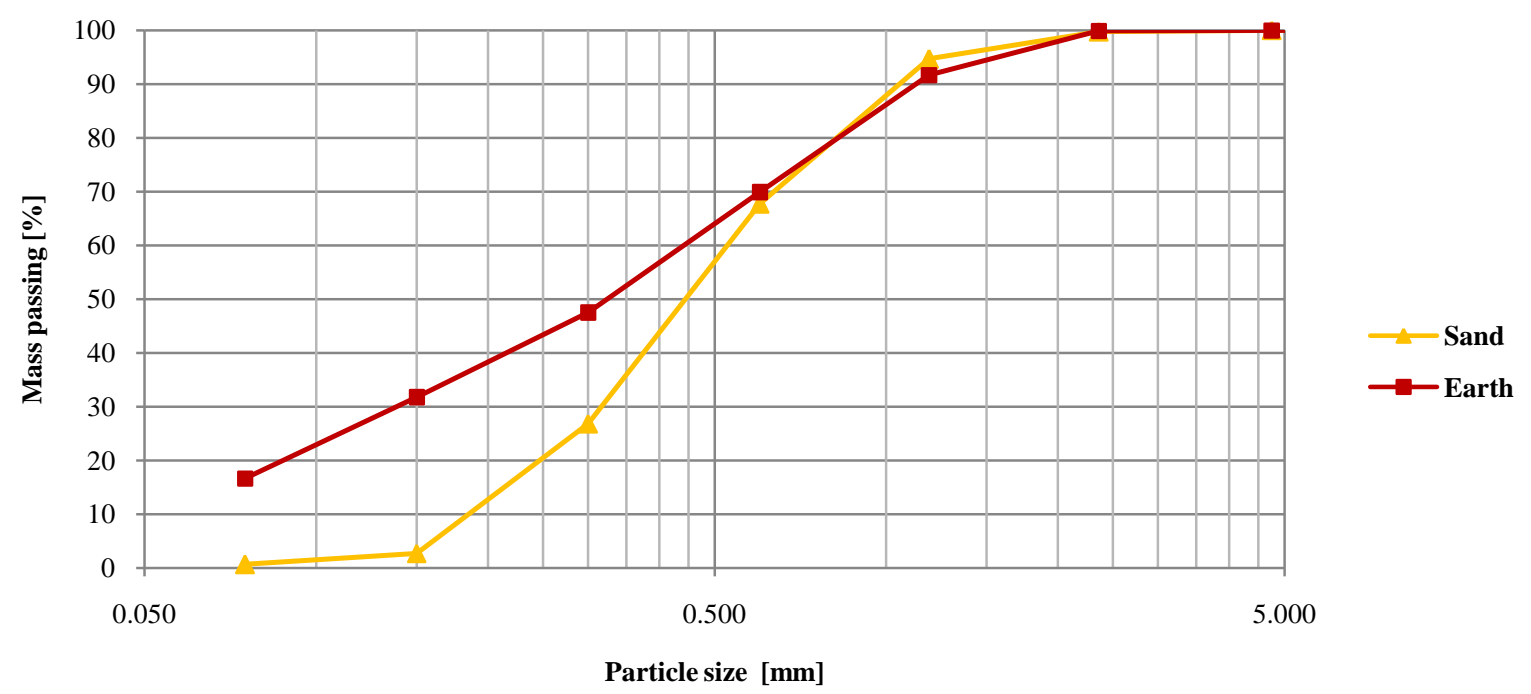

Figure 1 - Particle size distribution curves of clayish earth and sand.

The oat straw fibers added to two of the mortars were collected in a farm straw supplier and were cut to a maximum length of $20 \mathrm{~mm}$. After cutting the oat fibers were allowed to dry at open air, in containers protected with a fine aluminum mesh $(<2 \mathrm{~mm})$, during two summer weeks in Algarve hot and dry climate.

The typha spadixes that provided the typha fiber-wool for this experiment were harvested in the end of plant vegetative cycle (autumn) in a free water stream in hills Northeast sub-region of Algarve, where Typha latifolia L. is widely present in water streams ecosystems (Figure 2).
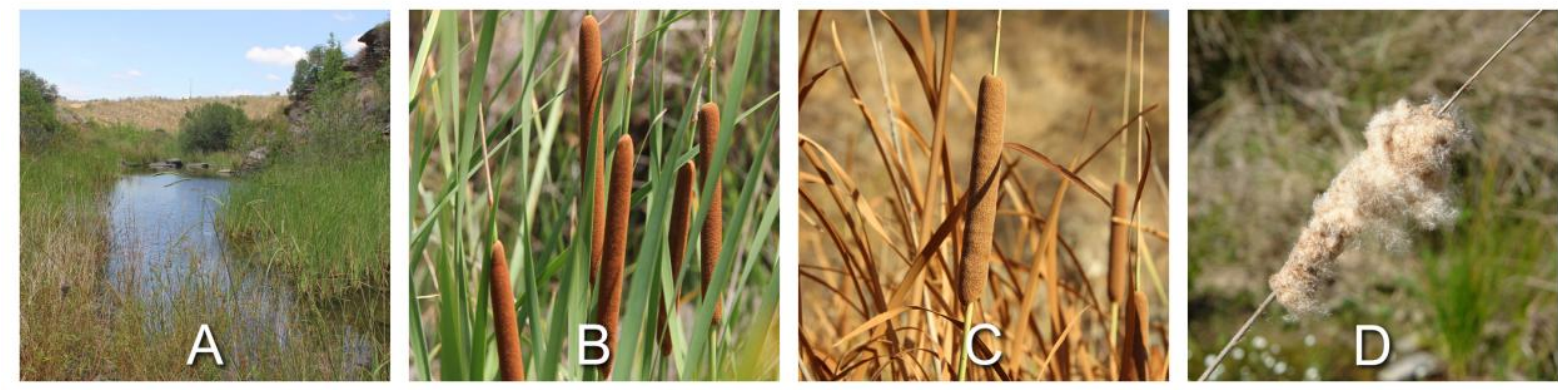

Figure 2 - (A) free water stream in hills Northeast sub-region of Algarve; (B) typha spadixes development; (C) dry typha spadixes in the end of vegetative cycle; (D) typha seed spreading from a spadix. 
After harvest the typha spadixes were also allowed to dry at open air, in containers protected from the wind with a fine aluminum mesh on top $(<2 \mathrm{~mm})$, till complete expansion of seeds (Figure 3). The expansion process of the typha seeds is spontaneous under certain conditions of warm temperature and dry relative humidity, and provide a ready-made dry fiber that can be easily added to mortars formulations dry mixture as a reinforcement in order to mitigate the chance of occurrence of shrinkage cracking during the drying of the plaster (Maddison et al., 2009; Georgiev et al., 2013).
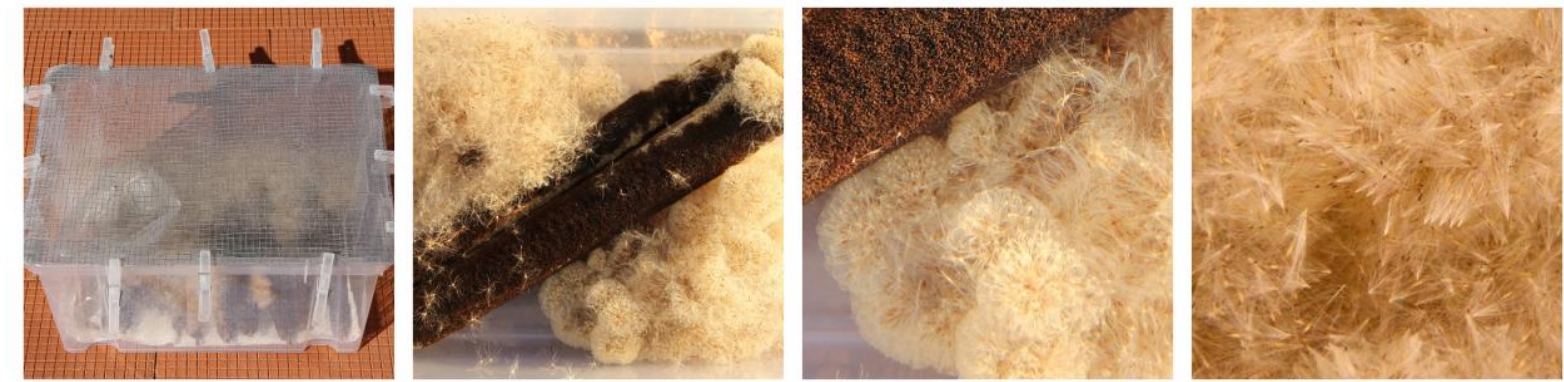

Figure 3 - Typha spadixes expantion.

\section{MORTAR'S FORMULATIONS AND FRESH STATE CHARACTERIZATION}

For the development of this study six mortars were formulated with the same volumetric proportions of clayish earth and siliceous sand, respectively 1:3. One of the mortars, referenced as E1S3, was formulated without any fiber addition to be taken as a reference mortar, while the other five mortars were added with different amounts of oat straw and typha fiber-wool. Mortars referenced as E1S3_OF10 and E1S3_OF20 were added with volumes of $10 \%$ and $20 \%$ of oat straw respectively (percentage of volume of both the clayish earth and sand). Mortars referenced as E1S3_TF20, E1S3_TF40 and E1S3_TF80 were added with volumes of $20 \%, 40 \%$ and $80 \%$ of typha fiber-wool respectively.

The standard DIN 18947 (DIN, 2013) was followed for preparing and mixing the mortars, as well as for fresh state characterization. The mortars were prepared with the minimum amount of water needed in order to achieve the flow table consistency defined in the DIN 18947 (175 $\pm 5 \mathrm{~mm}$ ) and ensuring a very good workability. Their proportions are registered in Table 1, in terms of volumetric ratios and weight ratios of clayish earth, sand, fibers and water contents. Wet density and flow table consistency were assessed.

Table 1 - Composition and fresh state mortars characterization.

\begin{tabular}{|c|c|c|c|c|c|c|c|c|c|c|}
\hline \multirow{2}{*}{$\begin{array}{c}\text { Mortar } \\
\text { reference } \\
\text { code }\end{array}$} & \multicolumn{4}{|c|}{ volume ratios } & \multicolumn{4}{|c|}{ weight ratios } & \multirow{2}{*}{$\begin{array}{c}\text { density } \\
\text { (fresh state) } \\
{\left[\mathrm{kg} / \mathrm{m}^{3}\right]}\end{array}$} & \multirow{2}{*}{$\begin{array}{c}\text { consistency } \\
\text { (flow table) } \\
{[\mathrm{mm}]}\end{array}$} \\
\hline & $\begin{array}{c}\text { earth } \\
{[\%]}\end{array}$ & $\begin{array}{l}\text { sand } \\
{[\%]}\end{array}$ & $\begin{array}{c}\text { fiber } \\
{[\%](\mathrm{ad})}\end{array}$ & $\begin{array}{c}\text { water } \\
{[\%](\mathrm{ad})}\end{array}$ & $\begin{array}{c}\text { earth } \\
{[\%]}\end{array}$ & $\begin{array}{l}\text { sand } \\
{[\%]}\end{array}$ & $\begin{array}{l}\text { fiber } \\
{[\%]}\end{array}$ & $\begin{array}{c}\text { water } \\
{[\%](\mathrm{ad})}\end{array}$ & & \\
\hline E1S3 & \multirow{6}{*}{25.0} & \multirow{6}{*}{75.0} & 0.0 & 19.6 & 21.6 & 78.4 & 0.0 & 12.8 & 2130.7 & 173.2 \\
\hline E1S3_OF10 & & & 10.0 & 22.1 & 21.5 & 78.0 & 0.5 & 14.4 & 2007.0 & 169.6 \\
\hline E1S3_OF20 & & & 20.0 & 25.0 & 21.4 & 77.6 & 1.0 & 16.2 & 1936.9 & 162.8 \\
\hline E1S3_TF20 & & & 20.0 & 21.7 & 21.6 & 78.3 & 0.1 & 14.2 & 2101.9 & 172.4 \\
\hline E1S3_TF40 & & & 40.0 & 22.5 & 21.6 & 78.3 & 0.1 & 14.7 & 2079.3 & 174.6 \\
\hline E1S3_TF80 & & & 80.0 & 25.6 & 21.6 & 78.2 & 0.3 & 16.7 & 2054.9 & 171.3 \\
\hline
\end{tabular}




\section{HARDENED STATE CHARACTERIZATION}

The hardened state characterization of the six mortars also followed the DIN 18947 (DIN, 2013). Prismatic $160 \mathrm{~mm}$ x $40 \mathrm{~mm}$ x $40 \mathrm{~mm}$ samples and circular $90 \mathrm{~mm}$ diameter and 20 $\mathrm{mm}$ thick samples were prepared in metallic molds, as well as samples of $20 \mathrm{~mm}$ mortar layer applied on hollow bricks. The mortars were assessed in terms of linear drying shrinkage, density, flexural, compressive and adhesive strength, as well as thermal conductivity and water vapor adsorption and desorption capacity. The first four tests used the prismatic samples, for adhesive strength the mortar layer on brick samples were used, while the circular samples were used for thermal conductivity.

The dynamic adsorption and desorption test was also conducted according to the DIN 18947 (DIN, 2013). For each mortar formulation three plaster samples were produced, with a surface area of $1000 \mathrm{~cm}^{2}(500 \mathrm{~mm} \times 200 \mathrm{~mm})$ and a thickness of $15 \mathrm{~mm}$. Each sample was prepared in a metallic molds to guarantee that adsorption and desorption would occur only in the top exposed surface.

The samples were stabilized in a climatic chamber (Figure 4) at $50 \%$ relative humidity (RH) and $23^{\circ} \mathrm{C}$. After the stabilization of the samples the climatic chamber condition was set to $80 \% \mathrm{RH}$ for the adsorption test phase. The samples were weighted at time intervals defined on the standard, respectively: $0.5 \mathrm{~h}, 1.0 \mathrm{~h}, 3 \mathrm{~h}, 6 \mathrm{~h}$ and $12 \mathrm{~h}$. The adsorption test was extended till $24 \mathrm{~h}$, beyond the $12 \mathrm{~h}$ interval defined in the standard, in order to achieve a more comprehensive understanding of the adsorption behavior of the samples. After $24 \mathrm{~h}$ the samples were weighted and the condition of the chamber was changed back to $50 \% \mathrm{RH}$, forcing the samples to a desorption phase, that was assessed with the same time interval protocol during another period of $24 \mathrm{~h}$.

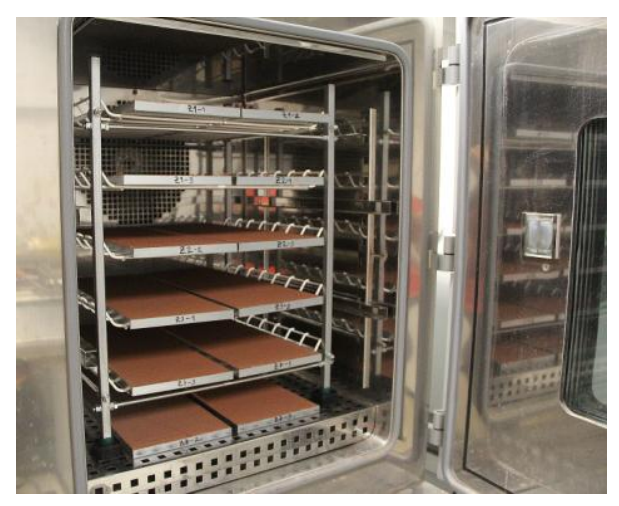

Figure 4 - Climatic chamber.

\section{RESULTS AND DISCUSSION}

The flow table consistency of all mortars complied with DIN 18947 (DIN, 2013) and it can be seen that the addition of both types of fibers decreased the wet density (Table 1). The decrease was lower with the addition of the typha-wool, most probably due to the small size of those fibers and the densification imposed on the mortar matrix, when compared with the coarser oat fibers.

The hardened state characterization reveals that all the six mortars present a significantly low linear drying shrinkage (less than 1.0\% - Figure 5), which is consistent with the low expansibility of the clayish earth used, which as a mineralogy dominated by illite clay mineral. As expected the addition of fibers to the mortars formulations contribute to decrease the samples linear shrinkage when compared with the reference mortars. However the 
increase of the fiber addition reveal the opposite effect, most probably due to the correspondent necessary increase of water to the mortar formulation in order to achieve workability and flow table consistency defined in DIN 18947 (Figure 5).

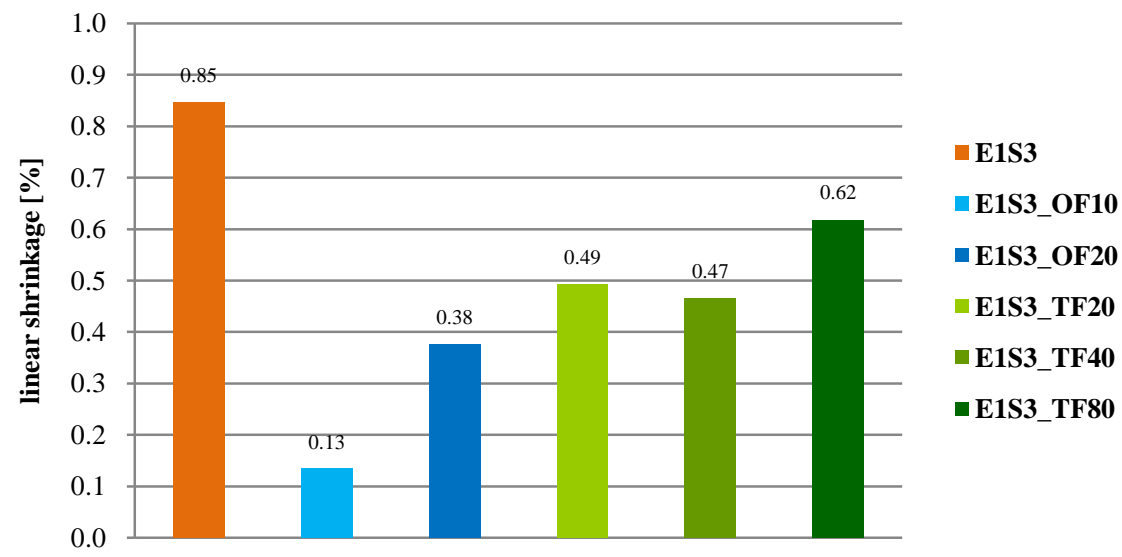

Figure 5 - Linear drying shrinkage.

Regarding hardened state density (Figure 6) according to DIN 18947 (DIN, 2013), it can be noticed the same tendency of the wet density. The reference mortar E1S3, formulated only with clayish earth and sand, falls within density class 2.0 (from $1.81 \mathrm{~kg} / \mathrm{dm}^{3}$ till $2.0 \mathrm{~kg} / \mathrm{dm}^{3}$ ). As expected the two mortars with addition of $10 \%$ and $20 \%$ of oat straw present lower density than the reference mortar, belonging to density class 1.8 (from $1.61 \mathrm{~kg} / \mathrm{dm}^{3}$ till $1.8 \mathrm{~kg} / \mathrm{dm}^{3}$ ), while the three mortars with addition of $20 \%, 40 \%$ and $80 \%$ of typha fiber-wool did not present a significant density decrease, falling within the same density class of the reference mortar.

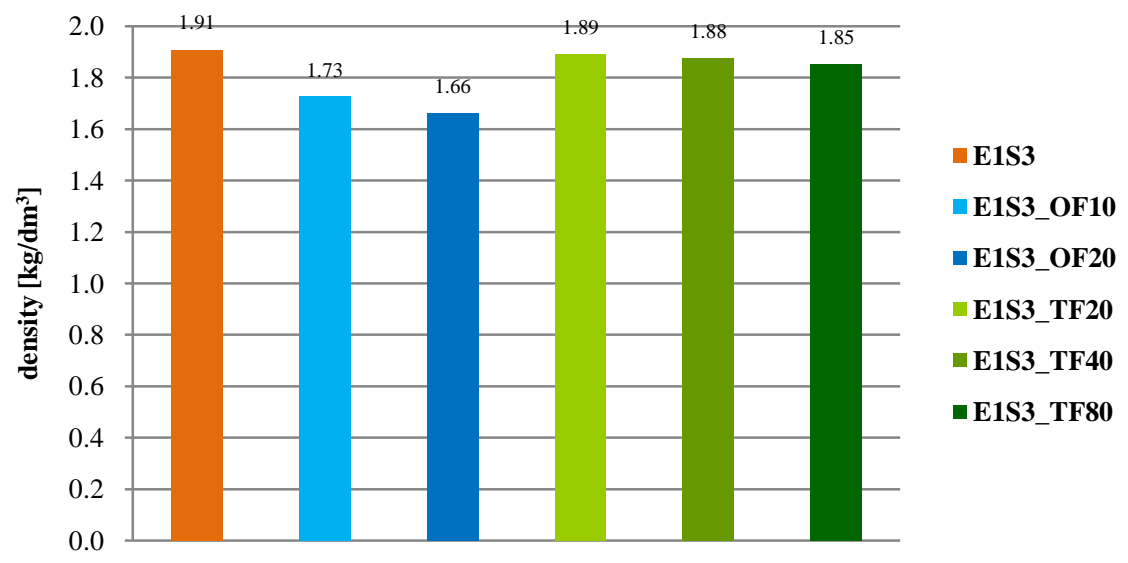

Figure 6 - Hardened state density.

The thermal conductivity test results (Figure 7) reveals, as expected, that the increase of the added volume of oat fibers promote the decrease of the thermal conductivity of the mortars, which is consistent with the decrease of mortars density. The same can be observed on mortars with the addition of typha fiber-wool; however when the results obtained by those mortars are compared with the reference mortar it can be remarked that the mortar with the lowest tytha fiber-wool volumetric addition achieve a slightly higher thermal conductivity than the reference mortar. Again, that may be due to a densification of the matrix pores with the addition of a small amount of this type of fibers. 


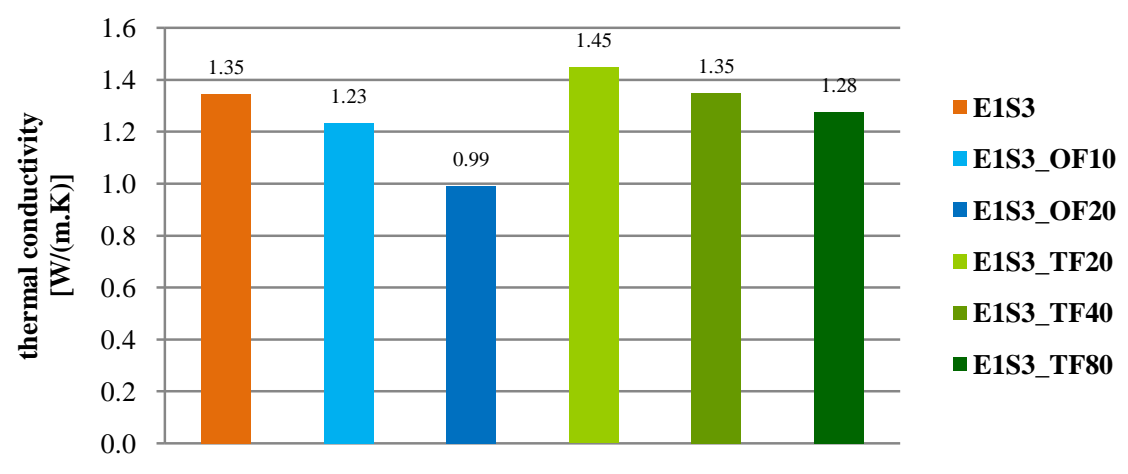

Figure 7 - Thermal conductivity.

Regarding flexural and compressive strength (Figure 8), mechanical tests showed that the reference mortar did not achieve (however by a short difference) the minimum values of mechanical resistance defined in the class S-I of the DIN 18947 (compressive strength $\geq 1.0$ $\mathrm{N} / \mathrm{mm}^{2}$; and flexural strength $\geq 0.3 \mathrm{~N} / \mathrm{mm}^{2}$ ). Concerning the addition of fibers, these mechanical tests reveal that the two types of natural fibers assessed on this study have a significantly different effect over flexural and compressive strength of the mortars.

The addition of oat straw remarkably decreased both flexural and compressive strength (from $9 \%$ to $21 \%$ on flexural strength and from $24 \%$ to $38 \%$ on compressive strength). This result was not expected and it seems to be related with the lower hardened state density of these mortars, which leads to mortars with reduced volumetric clay contents. However, and as expected, the increase of added volume of oat fibers promotes some improvement in both flexural and compressive strength.

The mortars with additions of $20 \%$ and $40 \%$ volume of typha fiber-wool showed an increase on both flexural and compressive strength (from $13 \%$ to $22 \%$ on flexural strength and from $11 \%$ to $15 \%$ on compressive strength), while the mortar with the addition of $80 \%$ volume of typha fiber-wool did not present significant differences. The results of the first two mortars are consistent with the expected reinforcement contribution of typha fiber-wool, and also with the hardened state density presented by these mortars, similar to the density of the reference mortar. This fact allows assuming that their clay contents will be also similar. The difference observed on mortar with an addition of $80 \%$ volume of typha fiber-wool may be justifiable due to the substantial amount of added water needed to process this mortar in order to achieve workability and the flow table consistency defined in DIN 18947.

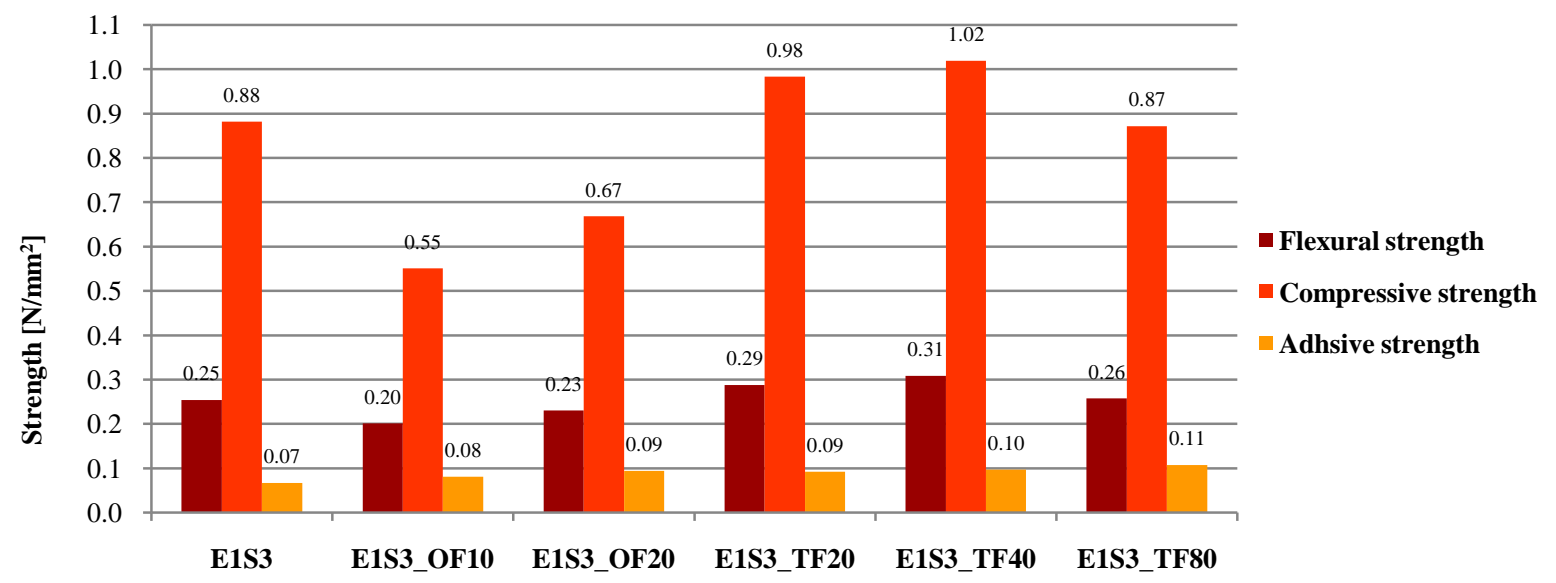

Figure 8 - Flexural, compressive and adhesive strength. 
From among the six mortars assessed in this study only the mortar with an addition of $40 \%$ volume of typha fiber-wool achieved the minimum values of mechanical resistance defined in class S-I of the DIN 18947 (compressive strength $\geq 1.0 \mathrm{~N} / \mathrm{mm}^{2}$; and flexural strength $\geq 0.3$ $\mathrm{N} / \mathrm{mm}^{2}$ ). This flexural and compressive strength results suggest that the mechanical resistance of these mortars should be improved, which considering the low expansibility of the clayish earth used (and low shrinkage) could be achieved through the formulation of mortars with higher concentrations of clayish earth content.

Nevertheless, according to DIN 18947 (DIN, 2013) the adhesion strength of all six mortars has complied with the minimum value of the resistance class S-I $\left(\geq 0.05 \mathrm{~N} / \mathrm{mm}^{2}\right)$. Furthermore the two mortars with higher addition of typha fiber-wool achieved the resistance class S-II $\left(\geq 0.10 \mathrm{~N} / \mathrm{mm}^{2}\right)$. These results showed also that all the mortars with the addition of natural fibers presents higher adhesion strength than the reference mortar, what is extremely important for plastering mortars. And among those mortars it is also possible to observe a trend of a slight increase of adhesion strength along with the increase of fiber addition.

The results of the dynamic adsorption and desorption test (Figure 9) indicate that all six mortars present a very high adsorption and desorption capacity. According to DIN 18947 (DIN, 2013) all mortars assessed in this study achieved adsorption values within the water adsorption class WS-III, the higher adsorption class defined in the standard $\left(\geq 60.0 \mathrm{~g} / \mathrm{m}^{2}\right.$ of adsorbed water vapor after $12 \mathrm{~h}$ at temperature of $23^{\circ} \mathrm{C}$ and a relative humidity of $80 \%$ ). The high adsorption and desorption capacity of the assessed mortars is consistent with previous research from the authors regarding the characterization of earth-based mortars formulated with different proportions of the same clayish earth, reveling clay content as the key factor on plaster adsorption and desorption capacity (Lima and Faria, 2014).

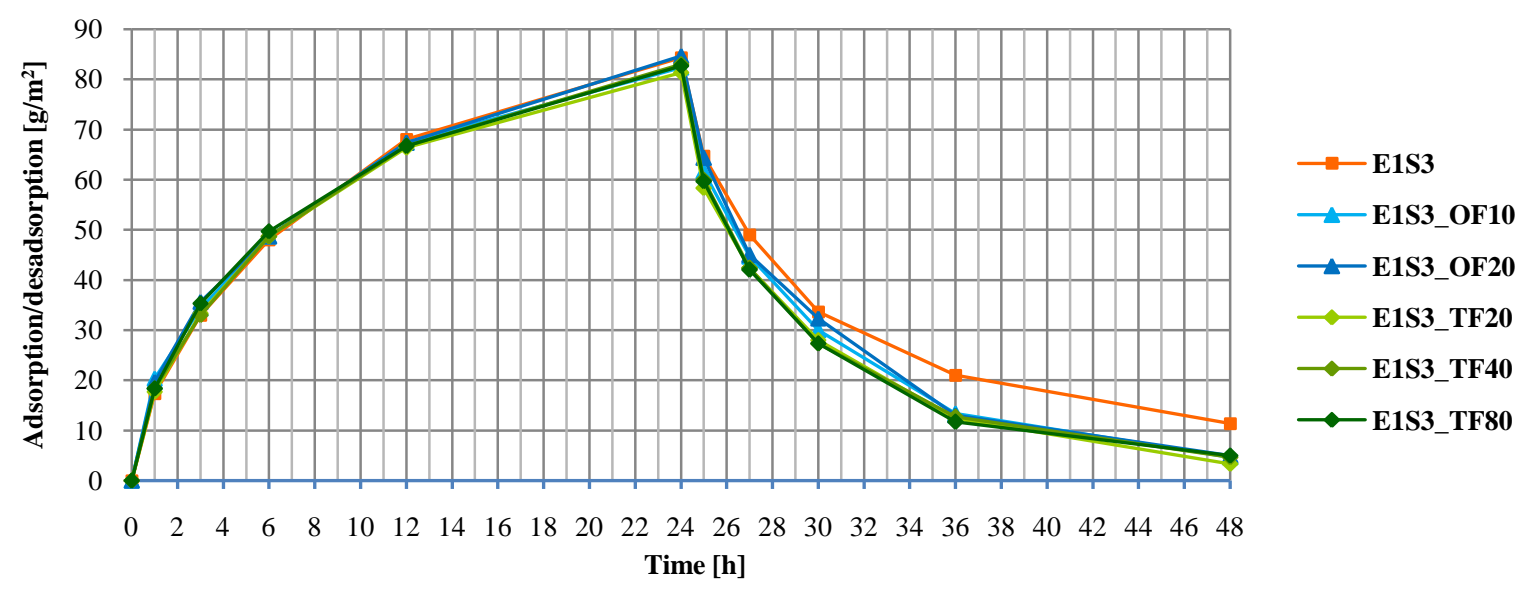

Figure 9 - Water vapor adsorption and desorption.

These results also show that all the six mortars have a similar dynamic behavior of adsorption and desorption, however showing some desorption delay, or hysteresis, being this effect most pronounced on the reference mortar. This desorption delay can generate a lag effect between consecutive cycles of adsorption and desorption, which could lead, over a certain period of time, to the decrease of adsorption and desorption capacity of the plaster, or even to its full moisture saturation.

In this study, although the different additions of oat fiber and typha fiber-wool showed to contribute to decrease the desorption delay, it was not possible to foresee from this results a clear influence of the amount of fibers added to mortars on their adsorption and desorption 
capacity, since all mortars with fiber additions reveal similar adsorption and desorption rates over time.

\section{CONCLUSIONS}

The results from this study showed that the addition of oat straw or typha fiber-wool can contribute to decrease linear drying shrinkage of a earth-based plaster, even when a clayish earth with low expansibility is used. However from a certain proportion the added fiber reveal the opposite effect, most probably due to the correspondent necessary increase of water to the mortar formulation.

As expected the increase of the added volume of oat straw or typha fiber-wool promote the decrease of the thermal conductivity of the mortars, which is consistent with the decrease of mortars density. However more research is need on this subject particularly regarding the influence of the addition of typha fiber-wool on mortars'microstructure.

The addition of the two types of natural fibers assessed on this study reveals to have a significantly different effect over flexural and compressive strength of mortars. The addition of oat straw remarkably decreased both flexural and compressive strength, while the addition of typha fiber-wool showed the opposite effect increasing both flexural and compressive strength. This may be due to the distinct particle size of the two types of fibers and different inclusion on the mortars'matrix. Furthermore from among the six mortars assessed in this study only the mortar with an addition of $40 \%$ volume of typha fiber-wool achieved the minimum values of mechanical resistance defined in DIN 18947 (DIN, 2013). This results suggest that the mechanical resistance of these mortars should be improved, which, considering the low expansibility of the clayish earth used, could be achieved through the formulation of mortars with higher clay content, what will be assessed in a future experimental campaign.

Nevertheless all the six mortars has complied with DIN 18947 (DIN, 2013) regarding adhesion strength, with positive reference being made for the mortars with typha fiber-wool addition, which achieved a promising adhesion strength, one of the most important properties for plasters.

As expected the adsorption and desorption test showed that assessed mortars present a very high adsorption and desorption capacity. All the mortars, regardless the different added volume of the two vegetal fibers, reveal a similar dynamic behavior of adsorption and desorption; however, showing some desorption delay. In consecutive cycles of adsorption and desorption this desorption delay can lead to the decrease of adsorption capacity of the plaster, or even to their moisture saturation. Although the additions of oat fiber and typha fiber-wool clear contributed to the decrease of the desorption delay, it was not possible to foreseen from this study the influence of the amount of fibers added to mortars on their adsorption and desorption capacity, since all mortars with fiber additions reveal similar adsorption and desorption rates over time. More research is needed in this subject in order to assess the extent of the desorption delay effect over long periods in real conditions, and also regarding the influence of the amount of fibers added to mortars on their adsorption and desorption capacity.

\section{ACKNOWLEDGMENTS}

The authors gratefully acknowledge the help of Vitor Silva on the experimental campaign held at NOVA University of Lisbon. 


\section{REFERENCES}

Botelho-Costa J, Caracterização e constituição do solo. $7^{\text {a }}$ edição. Lisboa: Fundação Calouste Gulbenkian, 1973. ISBN 972-31-0073-8.

Darling EK, Cros CJ, Wargocki P, Kolarik J, Morrison GC, Corsi RL. Impacts of a clay plaster on indoor air quality assessed using chemical and sensory measurements. Build Environ., 2012, 57, p-370-376.

Delinière R, Aubert JE, Rojat F, Gasc-Barbier M. Physical, mineralogical and mechanical characterization of ready-mixed clay plaster. Build. Environ, 2014, 80, p. 11-17.

DIN 18947. Earth plasters - Terms and definitions, requirements, test methods (in German), 2013.

Faria P, Santos T, Silva V. Earth-based mortars for masonry plastering. In: 9th International Masonry Conference, 2014 (CD).

Georgiev G, Theuerkorn W, Krus M, Kilian R. Cattail-reinforced clay plasters in building heritage preservation and new constructions. In: Correia M, Carlos G, Rocha S, editors. Vernacular Heritage and Earthen Architecture. CRC Press, 2013, p. 415-20.

Gomes C. Argilas: o que são e para que servem. $1^{\text {a }}$ edição. Lisboa: Fundação Calouste Gulbenkian, 1988.

Lamble SP, Corsi RL, Morrison GC. Ozone deposition velocities, reaction probabilities and product yields for green building materials. Atmospheric Environ., 2011,, 45(38), p. 69656972.

Lima J, Faria P, Earthen plasters: The potential of the clayey soils of Barrocal Region in Algarve. In: 40th IAHS World Congress on Housing - Sustainable Housing Construction , 2014. (CD-Rom ID-217, ISBN 978-989-98949-1-4).

Liuzzi S, Hall MR, Stefanizzi P, Casey SP. Hygrothermal behaviour and relative humidity buffering of unfired and hydrated lime-stabilised clay composites in a Mediterranean climate. Build. Environ., 2013, 61, p. 82-92.

Maddison M, Mauring T, Kirsimae K, Mander U. The humidity buffer capacity of clay-sand plaster filled with phytomass from treatment wetlands. Build. Environ., 2009, 44, p. 18641868.

Manuppella G, Moreira J, Grade J, Moura A, Contribuição para o conhecimento das características das argilas do Algarve. Porto: Estudos, Notas e Trabalhos do Serviço de Fomento Mineiro e Laboratório da D.G.G.M. Tomo 27, 1985. p.59-75.

Melià P, Ruggieri G, Sabbadini S, Dotelli G. Environmental impacts of natural and conventional building materials: a case study on earth plasters. J. Clean. Prod., 2014, 80, p. 179-186.

Minke G. Building with earth: design and technology of a sustainable architecture. Basel: Birkhauser - Publishers for Architecture, 2006. 199 p. ISBN-13: 978-3-7643-7477-8. ISBN10: 3-7643-7477-2.

Moret-Rodrigues A, Canha-Piedade A, Braga A. Térmica de edifícios. $1^{\text {a }}$ edição. Alfragide: Edições Orion, 2009. ISBN 978-972-8620-13-4.

WHO. Guidelines for indoor air quality: dampness and mould. Copenhagen: World Health Organization - Regional Office for Europe, 2009. ISBN 978-92-890-4168-3. 